\title{
Protein kinase C (PKC)- $\delta /-\varepsilon$ mediate the PKC/Akt-dependent phosphorylation of extracellular signal-regulated kinases 1 and 2 in MCF-7 cells stimulated by bradykinin
}

\author{
S Greco, C Storelli and S Marsigliante \\ Laboratory of Cellular Physiology, Department of Biological and Environmental Sciences and Technologies (DiSTeBA), Ecotekne, Via Provinciale per Monteroni, \\ 73100 Lecce, Italy \\ (Requests for offprints should be addressed to S Marsigliante; Email: santo.marsigliante@unile.it)
}

\begin{abstract}
In this paper the signal transduction pathways evoked by bradykinin (BK) in MCF-7 breast cancer cells were investigated. $\mathrm{BK}$ activation of the $\mathrm{B}_{2}$ receptor provoked: (a) the phosphorylation of the extracellular signalregulated kinases 1 and 2 (ERK1/2); (b) the translocation from the cytosol to the membrane of the conventional protein kinase $\mathrm{C}-\alpha(\mathrm{PKC}-\alpha)$ and novel $\mathrm{PKC}-\delta$ and PKC- $\varepsilon$; (c) the phosphorylation of protein kinase $\mathrm{B}$ (PKB/ Akt); (d) the proliferation of MCF-7 cells. The BKinduced ERK1/2 phosphorylation was completely blocked by PD98059 (an inhibitor of the mitogenactivated protein kinase kinase (MAPKK or MEK)) and by LY294002 (an inhibitor of phosphoinositide 3-kinase
\end{abstract}

(PI3K)), and was reduced by GF109203X (an inhibitor of both novel and conventional PKCs); Gö6976, a conventional PKCs inhibitor, did not have any effect. The BKinduced phosphorylation of $\mathrm{PKB} / \mathrm{Akt}$ was blocked by LY294002 but not by PD98059. Furthermore, LY294002 inhibited the BK-provoked translocation of $\mathrm{PKC}-\delta$ and PKC- $\varepsilon$ suggesting that PI3K may be upstream to PKCs. Finally, the proliferative effects of BK were blocked by PD98059, GF109203X and LY294002. These observations demonstrate that $\mathrm{BK}$ acts as a proliferative agent in MCF-7 cells activating intracellular pathways involving novel PKC- $\delta /-\varepsilon, \mathrm{PKB} / \mathrm{Akt}$ and ERK1/2.

Journal of Endocrinology (2006) 188, 79-89

\section{Introduction}

Bradykinin (BK) belongs to the kallikrein-kinin system and two G-protein-coupled receptors (GPCRs) have been recognised, namely, $\mathrm{B}_{1}$ and $\mathrm{B}_{2}$ receptors (Regoli \& Barabè 1980, Vavrek \& Stewart 1985, Ma et al. 1994, el-Dahr et al. 1997, Pesquero \& Bader 1998). In various cell types the $B_{2}$ receptor, as other GPCRs, mediates most of the biological actions of $B K$ via the activation of $G_{q / 11}$ protein, the increase of free intracellular calcium concentration $\left(\left[\mathrm{Ca}^{2+}\right]_{\mathrm{i}}\right)$ and the activation of various protein kinase C (PKC) isoforms (Enomoto et al. 1995, AnkorinaStark et al. 1997, Wiernas et al. 1998). It has also been clearly shown that BK treatment of different cell types leads to the activation of the mitogen-activated protein kinase (MAPK) cascade (Jaffa et al. 1997, Graness et al. 1998, Naraba et al. 1998). There are several modes of coupling of the $\mathrm{B}_{2}$ receptor to the MAPK extracellular signal-regulated kinases 1 and 2 (ERK1/2). For example, in endothelial cells the activation is mediated by $\mathrm{Ca}^{2+}$ dependent or -independent, but PKC $\varepsilon$-dependent, pathways (Flemming et al. 1995, Traub et al. 1997). PKC- $\varepsilon$ is also involved in ERK1/2 activation in fibroblasts, in rat myocytes and in the colon carcinoma cell line SW-480
(Clark \& Murray 1995, Clerk et al. 1996, Graness et al. 1998). In PC-12 phaeochromocytoma cells, a Ca ${ }^{2+}$ dependent epidermal growth factor receptor (EGFR) transactivation has been reported to be involved in BKmediated ERK1/2 activation (Hall 1992); conversely, in A431 epidermoid cells, BK transinactivates EGFR and, independently of EGFR, BK activates ERK1/2 through both phosphoinositide 3-kinase (PI3K) and PKC (Graness et al. 2000). BK is released by a kallikrein-kinin system, which is also present locally in breast tissue (Hermann et al. 1995), where the released kinin could participate in tumourigenesis (Clements \& Mukhtar 1977) and angiogenesis (Plendl et al. 2000) by increasing vascular blood flow and creating new capillary vessels. We have previously shown that in normal breast cells in primary culture the activation of $\mathrm{PKC}-\delta$ through the $\mathrm{B}_{2}$ receptor acts in concert with ERK1/2 and PI3K pathways to induce cell proliferation (Greco et al. 2004). Moreover, BK may have a role in breast cancer endorsement and progression since its mitogenic effects are also retained in primary cultured breast tumour cells, due to the operation of novel PKCs and ERK1/2 (Greco et al. 2005).

The expression of $\mathrm{B}_{2}$ receptors is also evident in two breast cancer cell lines, EFM-192A and MCF-7 
(Frey et al. 1999, Drube \& Liebmann 2000). In EFM192A cells, BK activates ERK1/2 through a PI3K/PKC pathway (Drube \& Liebmann 2000). In MCF-7 cells (Frey et al. 1999), it is known that $\mathrm{BK}$ increases the $\left[\mathrm{Ca}^{2+}\right]_{\mathrm{i}}$, but no further data about its downstream signalling mechanisms are available. Thus, in this paper we aimed to investigate the intracellular mechanisms activated by BK in MCF-7 cells, paying attention to those pathways previously highlighted in primary normal and cancerous breast cells (i.e. PKCs, PI3K/Akt and ERK1/2 signalling) (Greco et al. 2004, 2005); furthermore, the possibility that $\mathrm{BK}$ is mitogenic in MCF-7 breast cancer cells was also explored.

\section{Materials and Methods}

\section{Materials}

Dulbecco's modified Eagle's medium (DMEM), antibiotics, glutamine and foetal bovine serum (FBS) were purchased from Celbio (Pero, Milan, Italy). PKCs and ERK1/2 antibodies were purchased form Santa Cruz Biotechnology (DBA, Segrate, Italy) and monoclonal anti-PKB/Akt antibodies from Cell Signalling Technology (Celbio). Gö6976, GF109203X, PKC inhibitors and U73343 were purchased from Calbiochem (Milan, Italy). All other reagents were from Sigma.

\section{Cell culture}

Cells from the MCF-7 cell line, derived originally from human breast cancer pleural effusion were propagated in $75 \mathrm{~cm}^{2}$ flasks in DMEM containing 10\% FBS, $2 \mathrm{mM}$ glutamine and penicillin/streptomycin (100 U/100 mg per ml). Cells were grown at $37^{\circ} \mathrm{C}$ in a humidified atmosphere of $95 \%$ air:5\% $\mathrm{CO}_{2}$ and were used from passages $8-12$. For the experiments, at $75 \%$ confluence, the medium was replaced with DMEM without serum and cells were cultured for $48 \mathrm{~h}$.

\section{Immunoblot analysis}

Cells in flasks were incubated with agonist and/or inhibitors in DMEM without FBS for the required periods at $37^{\circ} \mathrm{C}$. The stimulation was stopped by transferring the flasks on ice. The cells were extracted with lysis buffer: $50 \mathrm{mM}$ Tris/ $\mathrm{HCl}$ (pH 7·5), $5 \mathrm{mM}$ EDTA, 2 mM EGTA, $1 \mathrm{mM}$ phenylmethylsulphonyl fluoride (PMSF), $1 \mathrm{mM}$ dithiothreitol (DTT), $0 \cdot 25 \mathrm{M}$ sucrose, $10 \mu \mathrm{g} / \mathrm{ml}$ aprotinin and $10 \mu \mathrm{g} / \mathrm{ml}$ leupeptin, and sonicated on ice $(3 \times 10-\mathrm{s}$ cycles). The mixture was centrifuged for $10 \mathrm{~min}$ at $800 \boldsymbol{g}$ and supernatant was saved and centrifuged at $100000 \boldsymbol{g}$ for $1 \mathrm{~h}$; supernatant was taken as the cytosol fraction. The pellet was resuspended in lysis buffer plus 1\% TritonX-100 and centrifuged as before; the supernatant was collected as the membrane fraction. Cellular lysates were used to study the expression of phospho-ERK1/2 or phospho-Akt; cytosols and membrane fractions were collected in order to detect PKC isozymes activation. We evaluated the $\mathrm{Na}^{+} / \mathrm{K}^{+}$-ATPase activity using a coupled enzyme assay method (Norby 1988) to determine the purity of the cell compartment fractions used for PKC immunoblotting. The enrichment factors (enzyme activities of final purified membrane pellet and cytosol compared with those of the initial homogenate) were $54 \cdot 3 \pm 6 \cdot 2$ and not determined (ND) respectively (data not shown). An equal amount of protein was solubilised in sample buffer by boiling for $5 \mathrm{~min}$ and subjected to $10 \%$ SDS-PAGE followed by electrotransfer on to a polyvinylidene fluoride (PVDF) membrane (Amersham). We used the rbbit antibodies against PKC isozymes and the monoclonal mouse antiserum anti-phosphorylated ERK1/2. Antibody anti-PKC- $\alpha$ was diluted 1:5000, while the other anti-PKC antibodies were diluted 1:1000; the anti-phosho-ERK1/2 and the anti-phospho-Akt antibodies were diluted 1:200 and 1:500 respectively. Membranes were incubated with the appropriate primary antibody and then with peroxidaseconjugated secondary antibodies diluted 1:10 000. As a control, the blots used for active ERK1/2 and PKB/Akt detection were then stripped and re-probed with other antibodies (Promega) which recognise both active and basal forms of the ERK and PKB/Akt enzymes.

Proteins were detected using enhanced chemiluminescence (ECL; Amersham). The intensity of the bands was quantified by scanning densitometry using the NIH Image 1.62 software (NIH, Bethesda, MD, USA).

\section{Proliferation assay by cell count}

MCF-7 cells were seeded at $2.5 \times 10^{4}$ cells/well on 24 well plates in DMEM growth medium with $10 \%$ FBS and incubated overnight at $37^{\circ} \mathrm{C}$ in a humidified environment containing $5 \% \mathrm{CO}_{2}$ to allow the adherence. The medium was changed to FBS-free growth medium for $48 \mathrm{~h}$ to induce quiescence. Agonists and inhibitors were diluted in FBS-free growth medium, and cells were counted in a Burker cell-chamber (Sigma) $24 \mathrm{~h}$ after treatment.

\section{Statistics}

Experimental points represent the mean \pm S.D. of three replicates measured on three cell cultures. Statistical analysis was carried out using Student's $t$-test for unpaired samples and ANOVA with Bonferroni-Dunn's test. Significance levels were chosen as $P<0.05$ for Student's $t$-test and $P<0 \cdot 005$ for Bonferroni-Dunn's test.

\section{Results}

\section{$B K$ provokes the phosphorylation of ERK1/2}

Serum-starved MCF-7 cells were incubated for various periods $(1,5,10,20,30,60$ and $180 \mathrm{~min})$ with $0 \cdot 1 \mu \mathrm{M} \mathrm{BK}$; 


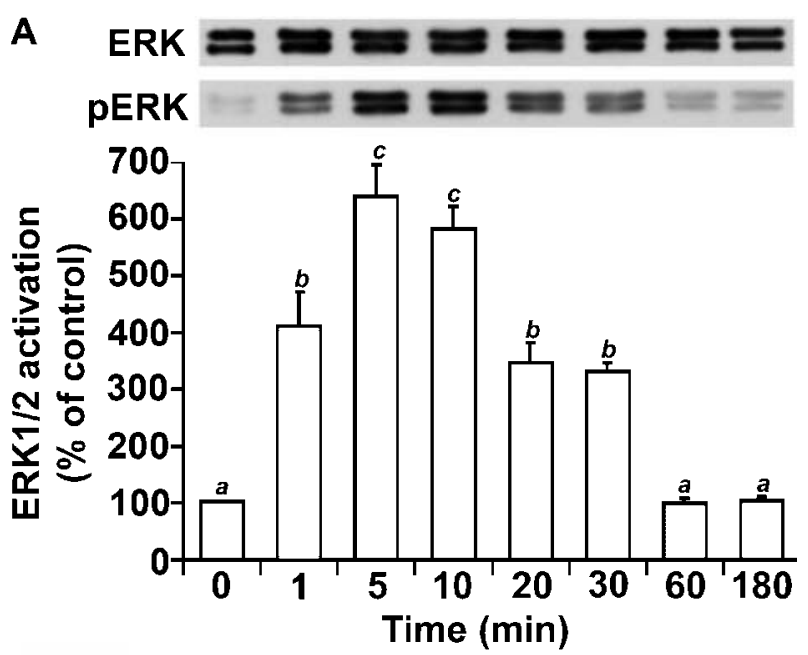

\section{B ERK}

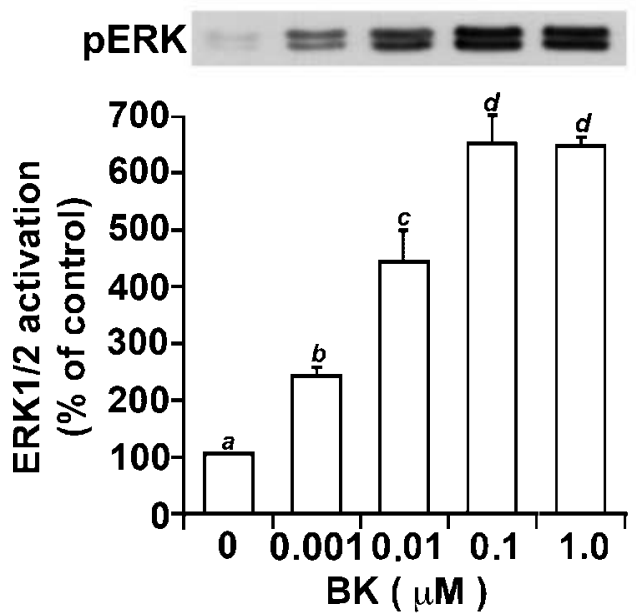

Figure 1 Activation of ERK1/2 by BK. MCF-7 cells were treated with $0 \cdot 1 \mu \mathrm{M} B K$ for increasing incubation times (A) or with increasing concentrations of BK for 5 min (B). Cell lysates were subjected to SDS-PAGE and probed with anti-phospho-ERK1/2, and then stripped and re-probed with anti-ERK1/2. Representative autoradiographs are shown and results are expressed as percentage ratio over cells at time $0 \mathrm{~min}(\mathrm{~A})$ or cells incubated in medium only (B) (control). Different letters indicate statistical differences found using Bonferroni-Dunn's test.

using the anti-phospho-ERK antibody, two bands of relative molecular mass $\left(M_{\mathrm{r}}\right) 42000$ and 44000 were detected in cell lysates, corresponding to $\mathrm{Tyr}^{204}$ phosphorylated ERK1 and 2 respectively. Phosphorylation was maximal at $5.0 \mathrm{~min}$ and returned to unstimulated levels at $60 \mathrm{~min}$ (ANOVA, $P<0 \cdot 0001$ ) (Fig. 1A). Thus, in order to study the dose-dependent phosphorylation of ERK1/2, cells were stimulated for 5 min using increasing concentrations of BK $(0 \cdot 001,0 \cdot 01,0 \cdot 1,1 \cdot 0 \mu \mathrm{M})$, and Fig. 1B shows that the maximum effect was obtained with $0 \cdot 1 \mu \mathrm{M}$ BK (ANOVA, $P<0 \cdot 0001$ ).
PD98059, a specific MEK inhibitor (Alessi et al. 1995), completely inhibited ERK1/2 phosphorylation at $10 \mu \mathrm{M}$ (ANOVA, $P<0 \cdot 0005)$ (data not shown).

The $B_{2}$ receptor is responsible for $B K$-mediated ERK1/2 activation

The receptor involved in $\mathrm{BK}$ effects was characterised using Hyp3-BK and Lys-BK, $\mathrm{B}_{2}$ and $\mathrm{B}_{1}$ receptor inhibitors respectively. We stimulated cells with and without $0 \cdot 1 \mu \mathrm{M}$ BK for $5.0 \mathrm{~min}$ after a $45 \mathrm{~min}$ treatment with increasing concentrations of $\mathrm{B}_{2}(0 \cdot 01,0 \cdot 1,1 \cdot 0$ and $10 \mu \mathrm{M})$ or $\mathrm{B}_{1}(1 \cdot 0,10$ and $100 \mu \mathrm{M})$ inhibitors. Hyp3-BK reduced the BK-mediated ERK1/2 phosphorylation dose dependently (ANOVA, $P<0 \cdot 0001$ ) (Fig. 2A), while Lys-BK did not have any effect (ANOVA, $P>0 \cdot 005$ ) (Fig. 2B), demonstrating that $\mathrm{B}_{2}$ was responsible for the $\mathrm{BK}$ effects.

Role of phospholipase $C-\beta$ (PLC- $\beta$ ) in the effects of $B K$ on MCF-7 cells

Frey et al. (1999) have demonstrated that BK increases $\left[\mathrm{Ca}_{2}+\right]_{\mathrm{i}}$, suggesting the involvement of the phospholipid pathway. To confirm the involvement of PLC- $\beta$ in the ERK1/2 phosphorylation, cells were incubated for $45 \mathrm{~min}$ with $0 \cdot 1,1 \cdot 0$ and $10 \mu \mathrm{M}$ U73122, a PLC- $\beta$ inhibitor, and then stimulated with $0.1 \mu \mathrm{M}$ BK for $5.0 \mathrm{~min}$. As shown in Fig. 3, U73122 completely inhibited the phosphorylation of ERK1/2 induced by BK (ANOVA, P<0.0001). The addition of $10 \mu \mathrm{M} \mathrm{U} 73343$ (an inactive analogue of U73122), used as negative control, for $45 \mathrm{~min}$ before $0 \cdot 1 \mu \mathrm{M}$ BK stimulation did not reduced ERK1/2 phosphorylation (Fig. 3).

\section{BK-mediated PKC isozyme cytosol-to-membrane translocations}

The PLC activity triggers the translocation from cytosol to membrane and thus the activation of PKC isozymes, either conventional (PKC- $\alpha,-\beta$ ), or novel (PKC- $\delta,-\varepsilon,-\eta$ and $-\theta)$, and such activation may be a mitogenic signal for breast cells (Lafon et al. 1995, Greco et al. 2003, 2004, 2005).

Incubation of cells with $0 \cdot 1 \mu \mathrm{M}$ BK provoked the translocation of PKC $-\alpha,-\delta$ and $-\varepsilon$ only, with maximal activation occurring at $5 \mathrm{~min}$ (Fig. 4A); all the other isoforms expressed by the MCF-7 cells and reported previously (Muscella et al. 2003) did not show any cytosol-to-membrane translocation (Fig. 4A). The role of PKC isozymes in ERK1/2 activation was studied by incubating cells for $45 \mathrm{~min}$ with or without $0 \cdot 1$ and $10 \mu \mathrm{M}$ Gö6976 (a PKC- $\alpha$ inhibitor), or $0 \cdot 1$ and $1 \cdot 0 \mu \mathrm{M}$ GF109203X (an inhibitor of both conventional and novel PKCs), before treatement with $0 \cdot 1 \mu \mathrm{M}$ BK for $5 \mathrm{~min}$. GF109203X completely inhibited the ERK1/2 phosphorylation induced by BK, while Gö6976 did not, 

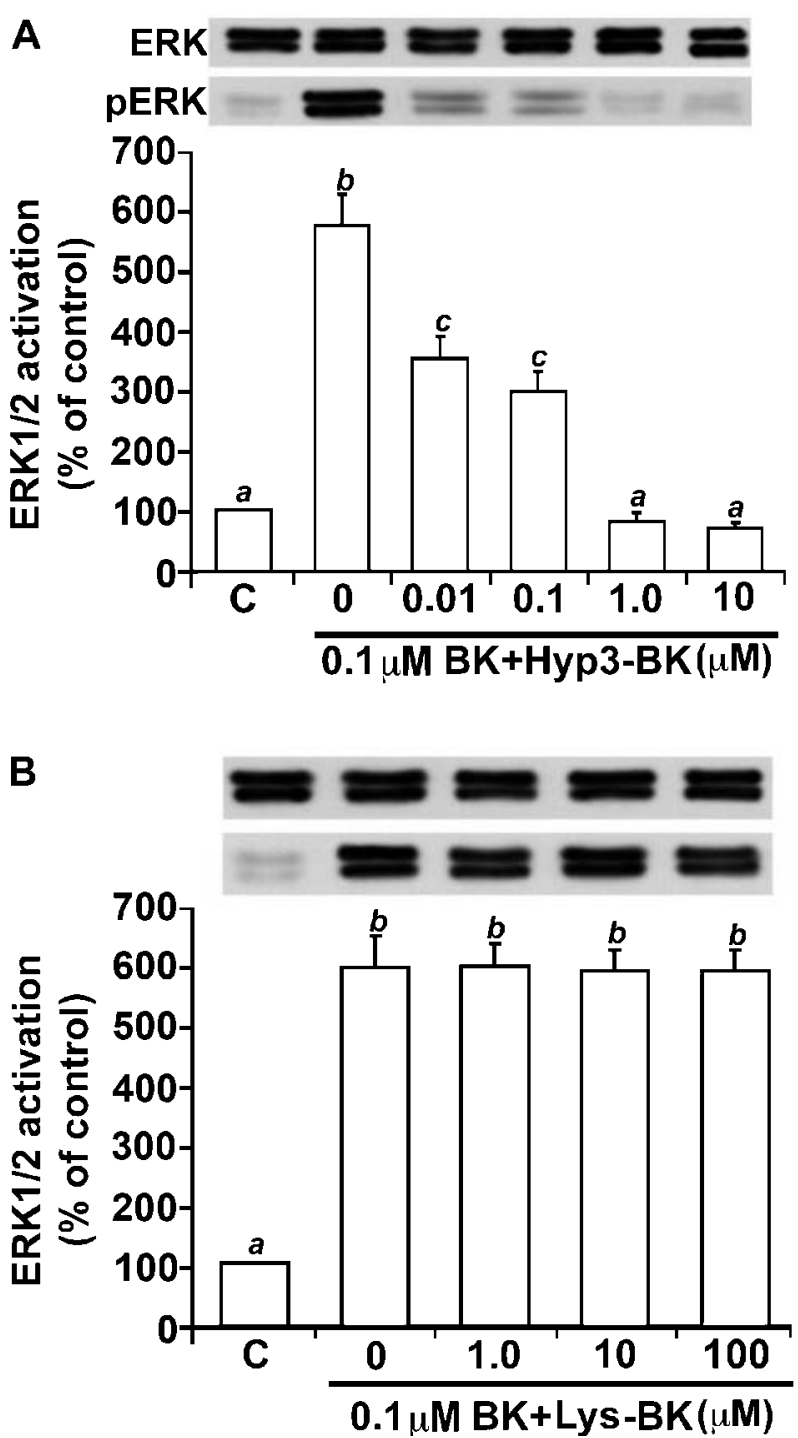

Figure 2 ERK $1 / 2$ activation by $B K$ is $B_{2}$ dependent. MCF-7 cells were treated for $45 \mathrm{~min}$ with increasing concentrations of Hyp3-BK ( $B_{2}$ inhibitor) $(A)$ or Lys (des-Arg-Leu)-BK ( $B_{1}$ inhibitor) (B) before adding $0 \cdot 1 \mu \mathrm{M}$ BK. Cell lysates were subjected to SDS-PAGE, probed with anti-phospho-ERK $1 / 2$, and then stripped and re-probed with anti-ERK $1 / 2$; results are expressed as the percentage ratio over cells incubated in medium only (C, control). Different letters indicate statistical differences found using Bonferroni-Dunn's test.

indicating a role for the novel $\mathrm{PKC}-\delta /-\varepsilon$ isozymes only (Student's $t$-test, $P<0 \cdot 005$; compared with control, cells incubated with BK only) (Fig. 4B).

\section{$B K$ provokes the phosphorylation of $P K B / A k t$}

A time-course study was conducted to determine the incubation times required for BK to stimulate phosphorylation of PKB/Akt. MCF-7 cells were stimulated

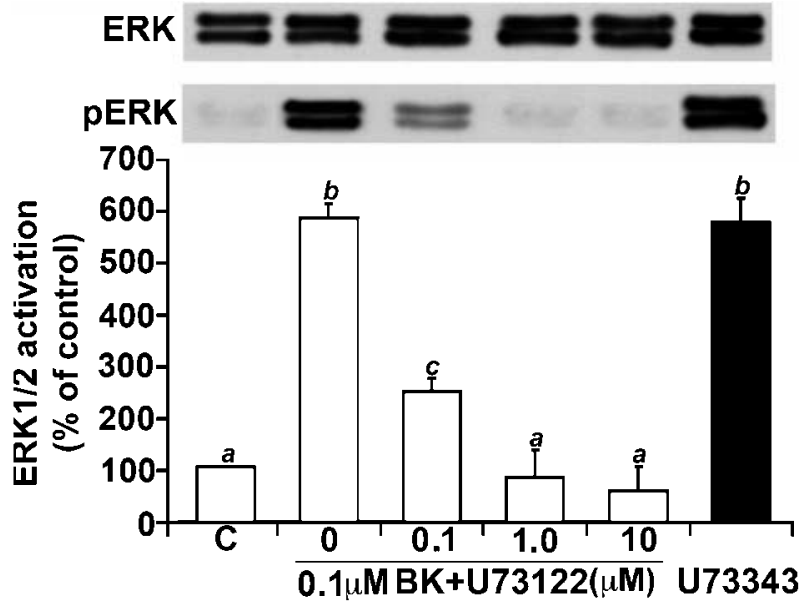

Figure $3 \mathrm{PLC}$ is involved in BK-dependent ERK $1 / 2$ activation. MCF-7 cells were treated for 45 min with increasing concentrations of U73122 or $10 \mu \mathrm{M} \cup 73343$, before stimulation with $0 \cdot 1 \mu \mathrm{M}$ BK for $5 \mathrm{~min}$. Cell lysates were subjected to SDS-PAGE, probed with anti-phospho-ERK $1 / 2$, and then stripped and re-probed with anti-ERK $1 / 2$; results are expressed as the percentage ratio over cells incubated in medium only (C, control). Different letters indicate statistical differences found using Bonferroni-Dunn's test.

with $0 \cdot 1 \mu \mathrm{M} \mathrm{BK}$, the concentration able to maximally activate ERK1/2, for periods of 5-220 min. The resolved proteins were immunoblotted with monoclonal antiphospho-Akt antibody which recognises $\mathrm{PKB} /$ Akt phosphorylated at $\mathrm{Ser}^{473}$. As shown in Fig. 5A, treatment of MCF-7 cells with BK stimulated PKB/Akt phosphorylation maximally at $60 \mathrm{~min}$ and then declined gradually (ANOVA, $P<0 \cdot 0001$ ) to basal level. Cells were then stimulated for $60 \mathrm{~min}$ using increasing concentrations of BK $(0 \cdot 01,0 \cdot 1$ and $1 \cdot 0 \mu \mathrm{M})$ and Fig. $5 \mathrm{~B}$ shows that $0 \cdot 1 \mu \mathrm{M}$ $\mathrm{BK}$ was the concentration able to give the highest activation of the enzyme (ANOVA, $P<0 \cdot 0001$ ).

MCF-7 cells were also pre-treated for 45 min with 10 and $30 \mu \mathrm{M}$ PD98059 and/or $0 \cdot 1 \mu \mathrm{M}$ BK for $60 \mathrm{~min}$; as shown in Fig. 5C, PD98059 did not have any effect on the BK-provoked PKB/Akt phosphorylation (Student's $t$-test, $P>0 \cdot 05$; compared with control, cells incubated with BK only).

Effect of LY294002 on ERK1/2 and PKB/Akt phosphorylation induced by $B K$

We further examined the effect of the PI3K inhibitor LY294002 on BK-induced PKB/Akt activation. LY294002 is a specific inhibitor of PI3K at low micromolar concentrations, but has no inhibitory effect on a number of tyrosine kinases at $50 \mathrm{mM}$ concentration (Vlahos et al. 1994).

Pre-treatment of MCF-7 cells with 5 and $15 \mu \mathrm{M}$ LY294002 attenuated the BK-stimulated phosphorylation 

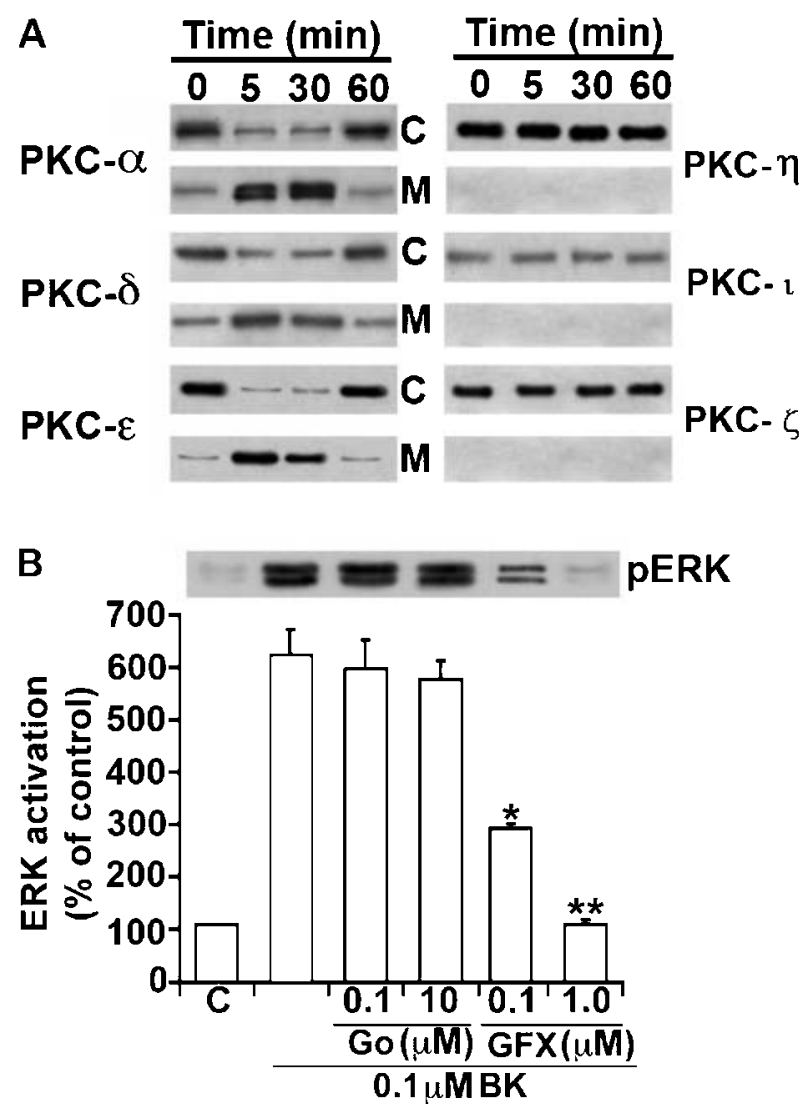

Figure 4 Involvement of PKC isozymes in BK-dependent mitogenic effects. (A) Representative autoradiographs of PKC isozyme translocations from cytosol (C) to membrane (M) provoked by $0 \cdot 1 \mu \mathrm{M}$ BK at the indicated periods. (B) MCF-7 cells were treated with and without $0 \cdot 1$ and $10 \mu \mathrm{M}$ Gö6976 or $0 \cdot 1$ and 1.0 $\mu \mathrm{M}$ GF109203X (GFX) for $45 \mathrm{~min}$ and then stimulated for 5 min with $0 \cdot 1 \mu \mathrm{M}$ BK. Cell lysates were subjected to SDS-PAGE, probed with anti-phospho-ERK $1 / 2$ and representative autoradiographs of ERK1/2 phosphorylation are shown. Result are expressed as the percentage ratio over cells incubated in medium only $(C$, control). Asterisks indicate statistical significance $(P<0.005)$ for Student's $t$-test compared with control, i.e. cells treated with BK only. ${ }^{*} P<0 \cdot 01 ;{ }^{*} P<0 \cdot 001$.

of $\mathrm{PKB} / \mathrm{Akt}$ in a concentration-dependent manner (Student's $t$-test, $P<0 \cdot 05$; as compared with the cells stimulated by agonist alone), showing a complete inhibition at $15 \mu$ M LY294002 (Fig. 6A). Moreover, LY294002 concentration-dependently inhibited the phosphorylation of ERK1/2 stimulated by BK (Student's $t$-test, $P<0 \cdot 05$; as compared with the cells stimulated by agonist alone) (Fig. 6B).

Effect of PKCs inhibition on PKB/Akt phosphorylation induced by $B K$

Cells were pre-treated with $10 \mu \mathrm{M}$ Gö6976 or $1 \cdot 0 \mu \mathrm{M}$ GF109203X for $45 \mathrm{~min}$ and then stimulated or not with
$0 \cdot 1 \mu \mathrm{M} \mathrm{BK}$ for $60 \mathrm{~min}$; as shown in Fig. 7A, only GF109203X inhibited the BK-dependent PKB/Akt phosphorylation, with Gö6976 showing no effects (Student's $t$-test, $P<0 \cdot 005$; as compared with the cells stimulated by BK alone) (Fig. 7A).

We also investigated the effect of PI3K inhibition on $\mathrm{PKC}-\delta$ and $-\varepsilon$ cytosol-to-membrane translocation obtained in cells stimulated with $0 \cdot 1 \mu \mathrm{M}$ BK for 5 min. The pre-treatment of MCF-7 cells for $45 \mathrm{~min}$ with $15 \mu \mathrm{M}$ LY294002 completely inhibited the BK-induced translocation of both PKCs (Fig. 7B).

\section{Proliferative effects of $B K$ in the MCF-7 cell line}

Increasing concentrations of BK $(0 \cdot 001,0 \cdot 01,0 \cdot 1,1 \cdot 0 \mu \mathrm{M})$ were used to stimulate serum-starved MCF-7 cells for $24 \mathrm{~h}$ and cell proliferation was quantified by cell count. BK increased cell proliferation in a dose-dependent manner with maximum effect at $0 \cdot 1 \mu \mathrm{M}$ (ANOVA, $P<0 \cdot 0001$ ) (Fig. 8A).

The MEK inhibitor PD98059 (0.01, 0.1, 1.0, 10 and $20 \mu \mathrm{M})$ was administered for $45 \mathrm{~min}$ before stimulating the cells with $0 \cdot 1 \mu \mathrm{M}$ BK for $24 \mathrm{~h}$. PD98059 provoked a significant dose-dependent decrease in the BK-induced proliferation of MCF-7 cells (ANOVA, $P<0 \cdot 0005$ ). A threshold decrease was observed at 0.01 $\mu$ M PD98059, with a maximum at $10 \mu \mathrm{M}$ (Fig. 8B).

The role of $\mathrm{PKC}-\delta$ and $-\varepsilon$ isozymes in the BK mitogenic pathway was studied by incubating the cells for $45 \mathrm{~min}$ with or without GF109203X $(0 \cdot 01,1 \cdot 0$ and $10 \mu \mathrm{M})$ before treatment with $0 \cdot 1 \mu \mathrm{M}$ BK for $24 \mathrm{~h}$. A dose of $1.0 \mu \mathrm{M}$ GF109203X completely inhibited the proliferation induced by $\mathrm{BK}$, thus indicating a role for the novel PKC isozymes (ANOVA, $P<0 \cdot 0005$ ) (Fig. 8C).

Finally, the role of the PI3K/Akt pathway was investigated using LY294002. Cells were pre-treated with or without LY294002 (5, 15 and $50 \mu \mathrm{M})$ for $45 \mathrm{~min}$ and then stimulated for $24 \mathrm{~h}$ with $0 \cdot 1 \mu \mathrm{M}$ BK. A dose of $15 \mu \mathrm{M}$ LY294002 completely inhibited the proliferation induced by BK (ANOVA, $P<0 \cdot 0001$ ) (Fig. $8 D$ ).

\section{Discussion}

The proliferation of breast epithelial cells is a key underlying event involved in breast diseases including cancer. The proliferative response of breast epithelial cells may be regulated by autocrine and paracrine stimuli. The effects of BK, to which breast epithelial cells may be exposed for either short or prolonged durations, have been explored using primary cultured normal and cancerous human breast epithelial cells (Greco et al. 2004, 2005). It was found that in both normal and cancerous cells BK has consistent mitogenic effects exerted through the ERK1/2 pathway. Such effects were also indicated by others in 
A

A

Akt

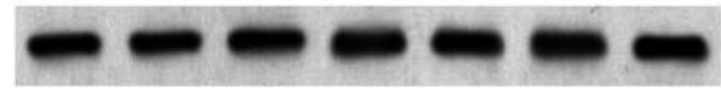

pAkt

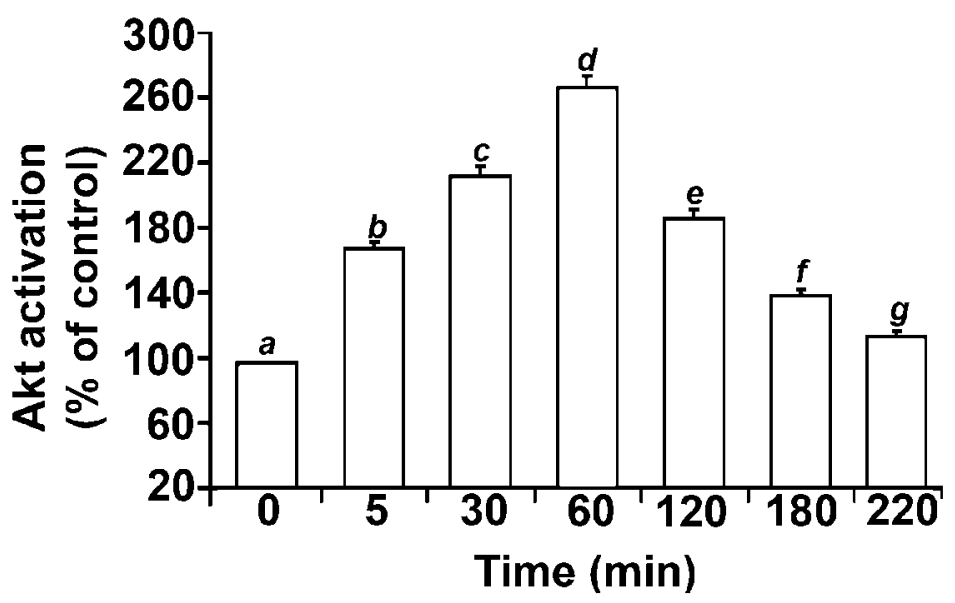

B
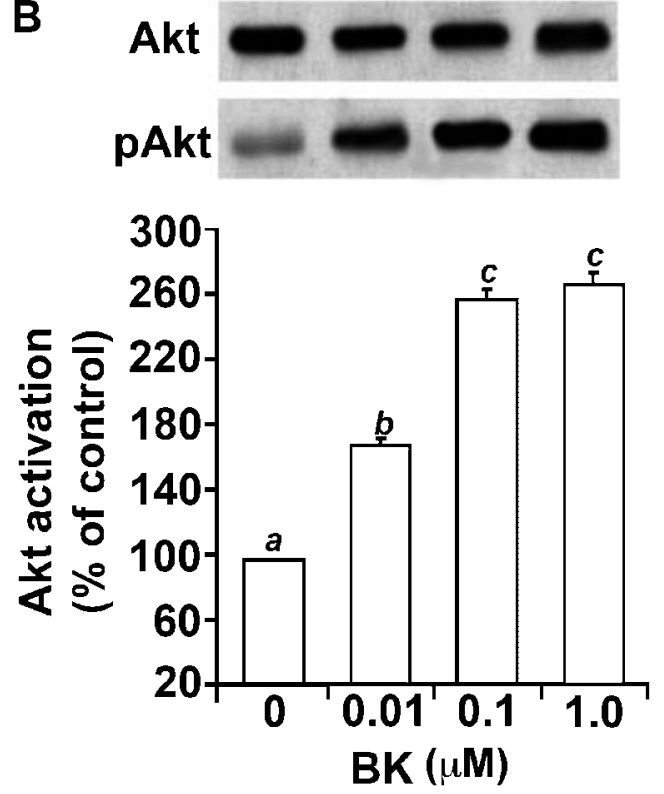

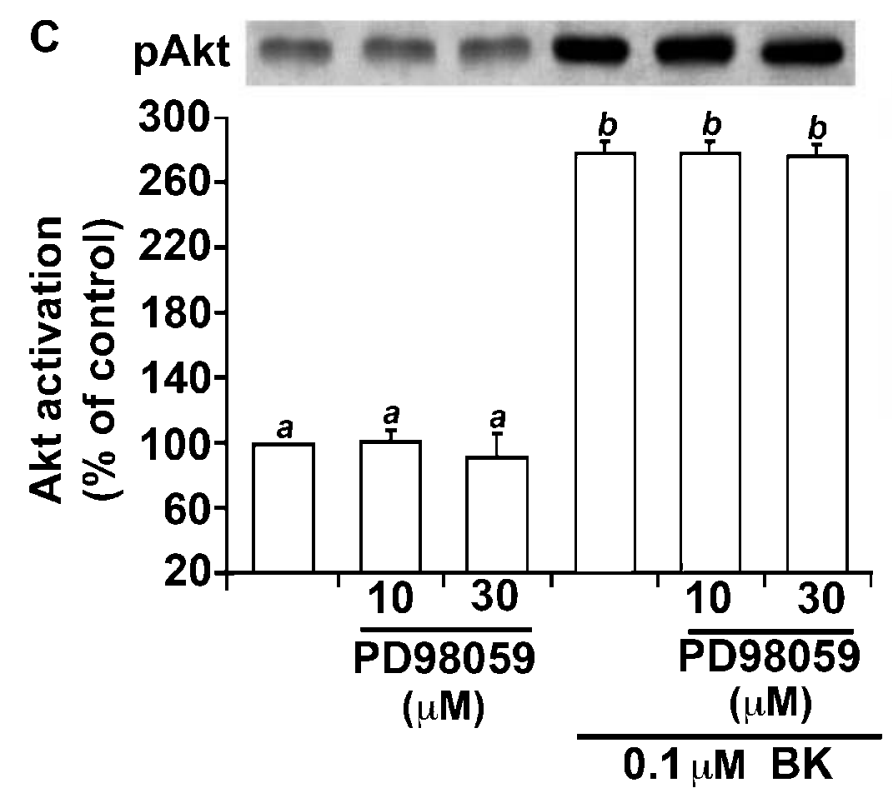

Figure 5 Akt phosphorylation stimulated by BK. MCF-7 cells were stimulated with BK $(0 \cdot 1 \mu \mathrm{M})$ for increasing incubation times (A) or with increasing BK concentrations for $60 \mathrm{~min}$ (B). The resolved proteins were immunoblotted with anti-phospho-Akt, and after stripping with anti-total Akt. Results are expressed as the percentage ratio over cells incubated at time 0 or in medium only. Different letters indicate statistical differences found using Bonferroni-Dunn's test. (C) Cells were pre-treated for 45 min with 10 and $30 \mu \mathrm{M}$ PD98059 and then stimulated or not with $0 \cdot 1 \mu \mathrm{M}$ BK for $60 \mathrm{~min}$. The resolved proteins were immunoblotted with anti-phospho-Akt.

EFM-192A, a breast cancer cell line (Drube \& Liebmann 2000). In another well characterised breast cancer cell model, MCF-7, information regarding the role of BK on cell proliferation has so far not been published; however, previous studies have shown that the MCF-7 cells were indeed a target of BK, in as much as it evoked a substantial intracellular free $\mathrm{Ca}^{2+}$ increase (Frey et al. 1999). In this study, we demonstrated that BK induces activation of ERK1/2 via the $B_{2}$ receptor. The intracellular routes by which this activation occurred were studied and involved 


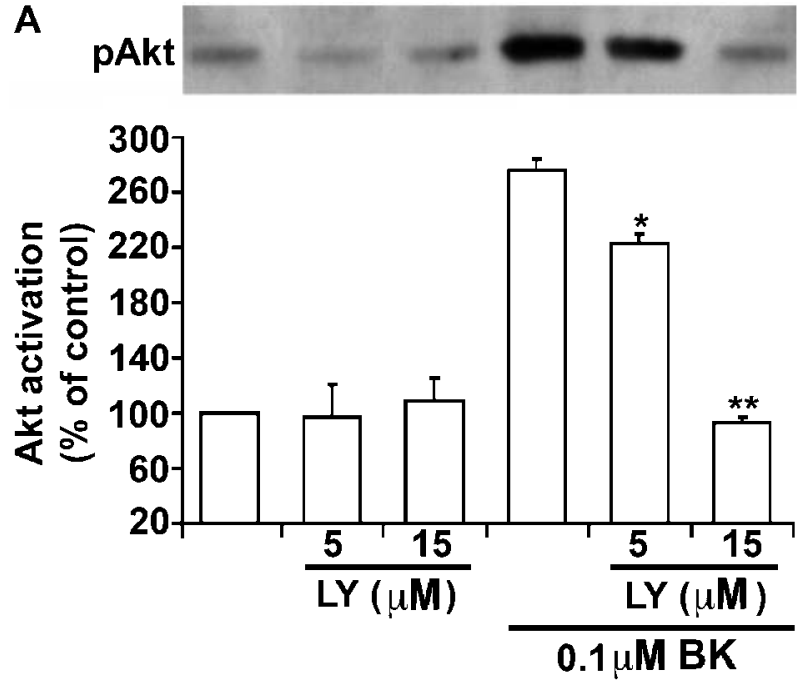

B
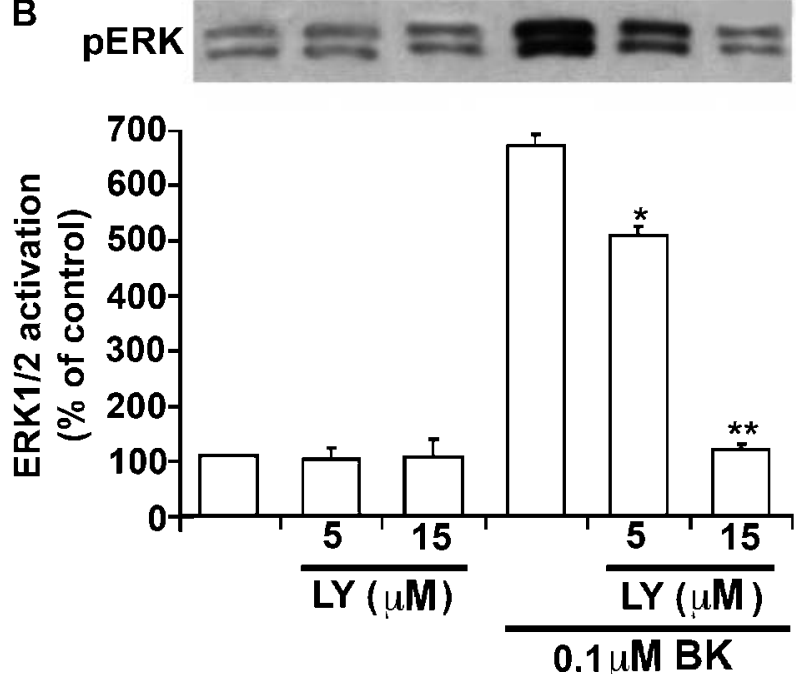

Figure 6 Role of PI3K on Akt and ERK1/2 phosphorylation induced by BK. MCF-7 cells were pre-treated for 45 min with 5 and $15 \mu \mathrm{M}$ LY294002 (LY) and then stimulated with $0 \cdot 1 \mu \mathrm{M} \mathrm{BK}$ for 60 or $5 \mathrm{~min}$, for Akt or ERK1/2 activation respectively. Cells were also treated for 45 min with 5 and $15 \mu \mathrm{M}$ LY294002 only. The resolved proteins were immunoblotted with anti-phospho-Akt, and after stripping with anti-total Akt (A) or with anti-phospho-ERK $1 / 2$ and then stripped and re-probed with anti-ERK1/2 (B). Results are expressed as the percentage ratio over cells incubated in medium only. Asterisks indicate statistical significance for Student's $t$-test compared with the cells stimulated by agonist alone. ${ }^{*} P<0 \cdot 01 ;{ }^{*} P<0 \cdot 001$.

the operation of novel PKCs and PI3K/Akt pathways, ending in the stimulation of cell proliferation. Drube and Liebmann (2000), have also shown the involvement of the PI3K pathway in the activation of the MAPK cascade, but here we show for the first time in breast cancer cells, that novel PKC isozymes can act as a link between the $\mathrm{B}_{2}$ receptor and Akt phosphorylation.

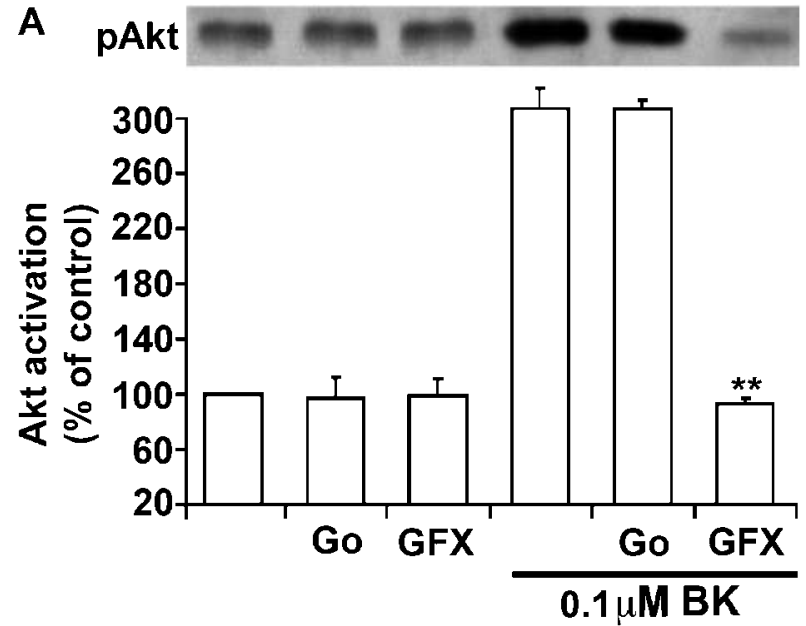

B

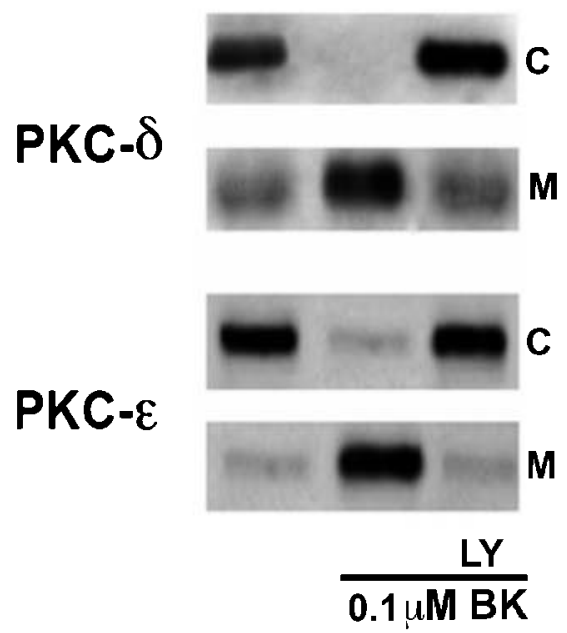

Figure 7 Role of the novel PKCs in the PI3K/Akt pathway. (A) Serum-starved cells were pre-treated with $10 \mu \mathrm{M}$ Gö6976 or 1.0 $\mu \mathrm{M}$ GF109203X for $45 \mathrm{~min}$ and then stimulated or not with $0 \cdot 1 \mu \mathrm{M}$ BK for $60 \mathrm{~min}$. Asterisks indicate statistical significance for Student's $t$-test compared with the cells stimulated by agonist alone. (B) LY294002 (15 $\mu \mathrm{M})$ was also administered for $45 \mathrm{~min}$ before $0 \cdot 1 \mu \mathrm{M}$ BK for $5 \mathrm{~min}$; the resolved membrane $(\mathrm{M})$ and cytosolic (C) protein fractions were then probed with antiserum anti-PKC- $\delta$ or $-\varepsilon$.

We show here that in MCF-7 cells a functional $\mathrm{B}_{2} \mathrm{BK}$ receptor enables ERK1/2 phosphorylation. The expression of BK receptors has been proved in a small cell lung carcinoma cell line $\mathrm{H}-69$, in a breast cancer cell line EFM-192A, in a colon carcinoma cell line SW-480 (Drube \& Liebmann 2000) and in the androgenindependent prostate cancer cells PC3 (Barki-Harrington \& Daaka 2001). Most of the biological actions of the $B_{2}$ receptor are mediated via $\mathrm{Gq} / 11$ protein leading to an increase in $\left[\mathrm{Ca}^{2+}\right]_{\mathrm{i}}$ and $\mathrm{PKC}$ activation in different cell types (Enomoto et al. 1995, Ankorina-Stark et al. 1997, 

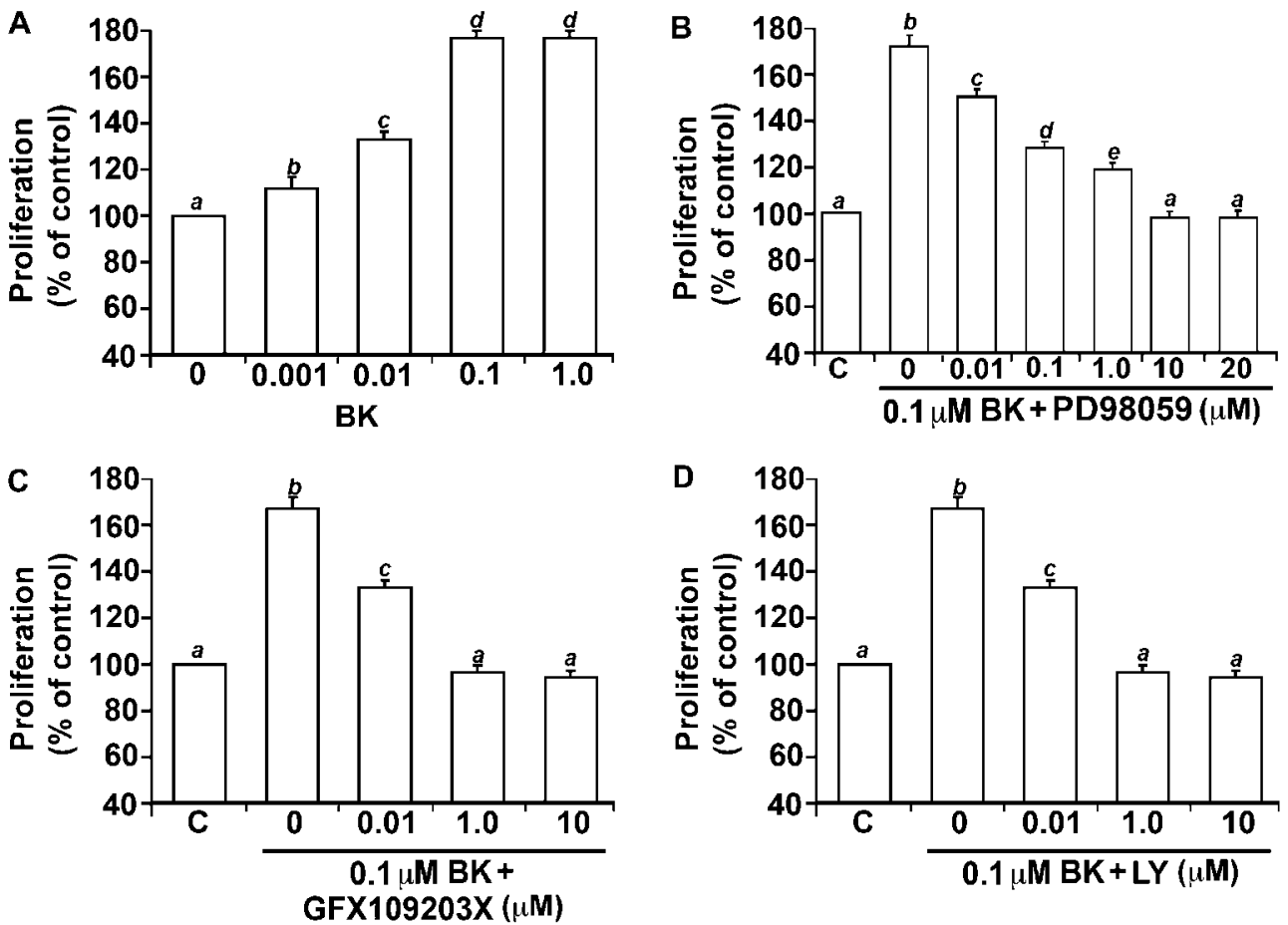

Figure 8 BK as a mitogen for breast cancer cells. (A) Serum-starved MCF-7 cells were incubated with increasing concentrations of BK for $24 \mathrm{~h}$. Cell proliferation was measured by cell count using a Burker cell chamber and results were compared with cells incubated in medium only. Serum-starved MCF-7 cells were treated with increasing concentrations of PD98059 (B), GF109203X (C) or LY294002 (LY; D), before treatment for $24 \mathrm{~h}$ with $0 \cdot 1 \mu \mathrm{M}$ BK. Cell proliferation was measured by cell count using a Burker cell chamber and results were compared with controls (letter ' $C$ ' in panels B-D), i.e. cells incubated in medium only. Different letters indicate statistical differences found using Bonferroni-Dunn's test.

Wiernas et al. 1998). The involvement of PLC in the mitogenic effect of BK in MCF-7 cells has been proved using U73122 which totally inhibited this effect (Fig. 3). As a result of PLC activation, $\mathrm{B}_{2}$ exerted the cytosol-tomembrane translocation of the conventional PKC- $\alpha$ and the novel PKC- $\delta$ and $-\varepsilon$ (Fig. 4); the latter were clearly linked to the ERK1/2 pathway since their inhibition, but not the inhibition of PKC- $\alpha$ obtained by Gö6976 (Fig. 4), blocked the phosphorylation of ERK1/2. The involvement of novel PKCs in the ERK1/2 activation by BK has also been shown previously in normal and cancerous breast cells in primary culture (Greco et al. 2004, 2005). This transduction mechanism seems therefore to be a hallmark in the way in which ERK1/2 is linked to BK signalling in the human breast, MCF-7 cells included. Indeed, MAPK may be coupled to the $\mathrm{B}_{2}$ receptor in several ways. In $\mathrm{B}_{2}$-transfected COS-7 cells both the activation of the PKC pathway and the EGFR transactivation comes about before the activation of MAPK (Adomeit et al. 1999). In PC-12 cells, EGFR transactivation (Zwick et al. 1997) as well as activation of a Pyk2/Src pathway (Dikic et al. 1996) are involved in BK-mediated MAPK activation. Translocation of PKC isozymes to the membrane are mitogenic signals for the cells (Lafon et al. 1995, Greco et al. 2003, 2004) and can result in the phosphorylation of ERK1/2. In A431 cells, $B_{2}$ induces MAPK activation through a pathway involving both PI3K and PKC, and resulting in the inhibition of EGFR activity (Graness et al. 1998).

PI3K activity has, from the start, been linked with many aspects of cell transformation processes, including increased cell growth, proliferation and survival, adhesion, metastasis and angiogenesis (Roymans \& Slegers 2001). Disturbances in the PI3K pathway block MAPK activation (Hawes et al. 1996, Kranenburg et al. 1997, Wennstrom \& Downward 1999) suggesting a role for PI3K in MAPK function. The PI3K/Akt pathway in MCF-7 cells appears to be involved in ERK1/2 activation since LY294002 provoked a complete inhibition of the BK-induced phosphorylation of ERK1/2 (Fig. 6B). Several lines of evidence have indicated that the serine/ threonine Akt (also known as protein kinase B, PKB) mediates many of the downstream events controlled by PI3K (Crowder \& Freeman 1998, Riera et al. 2003). $\mathrm{PKB} /$ Akt is activated by phospholipid binding, by PDK1 phosphorylation at Thr308 (Alessi et al. 1996) and by 
phosphorylation within the carboxy-terminus at $\mathrm{Ser}^{473}$. While in primary cultured normal and cancerous breast cells it was shown that the activity of PI3K is required to bring about the effects of BK on ERK1/2 (Greco et al. 2004, 2005), no data were provided regarding the involvement of the PI3K downstream kinase PKB/Akt. We showed here that indeed BK phosphorylates PKB/ Akt in MCF-7 cells both time and dose dependently, and that this effect was not reduced by PD98059; indicating that ERK1/2 are not required for the PKB/Akt activation mediated by BK (Fig. 5). Conversely, when the PI3K pathway is inhibited by LY294002, the BK-dependent phosphorylation of $\mathrm{PKB} / \mathrm{Akt}$ is obviously inhibited, but also the phosphorylation of ERK1/2 appeared blunted, suggesting that the activation of PI3K/Akt may be upstream to ERK1/2 activation (Fig. 6). Novel PKCs could be a link connecting PI3K to ERK1/2 since GF109203X completely blocked the phosphorylation of $\mathrm{PKB} / \mathrm{Akt}$ (Fig. 7A). In fact, the phosphorylation of Akt was maximal at $60 \mathrm{~min}$ (Fig. 5), whereas ERK1/2 appeared to be maximally phosphorylated at 5 min (Fig. 1). Nevertheless, after $5 \mathrm{~min}$ the phosphorylation of Akt was about 1.7-fold the basal unstimulated level; we hypothesise that this activity is sufficient to activate the MAPK cascade.

In epithelial breast cells, BK provokes a PKCdependent activation of the ERK1/2 signalling cascade leading to stimulation of cell proliferation (Greco et al. 2004, 2005); data shown here also indicate that the BK-provoked $\mathrm{PKC}, \mathrm{PKB} / \mathrm{Akt}$ and ERK1/2 activation are a mitogenic signal for MCF-7 cells. Of these pathways, $\mathrm{PKB} / \mathrm{Akt}$ appears responsible for the activation of novel PKCs, while ERK1/2 are ultimately responsible for cell proliferation and depend upon both novel PKCs and PI3K activities. These data are in accordance with substantial evidence about the involvement of PI3K in BK-provoked cell proliferation, as shown in different human cancer cell lines - such as the EFM-192A (breast), the EFE-184 (endometrium) and the T-24 (bladder) cell lines (Drube \& Liebmann 2000).

Here we showed for the first time that by inhibiting $\mathrm{PI} 3 \mathrm{~K} / \mathrm{Akt}$ activity the BK-dependent $\mathrm{PKC}-\delta$ and $-\varepsilon$ translocations are prevented (Fig. 7B), indicating a PI3K/ Akt-dependent regulation of PKC. As discussed above, the PKC-dependent regulation of Akt is well known, but so is a PI3K/Akt-dependent modulation of PKC activity. In fact, several authors (Zhang et al. 1995, Akimoto et al. 1996, Moriya et al. 1996), suggested that PI3K activity through the generation of $3^{\prime}$-phosphorylated lipids can act as a second messenger for the regulation of most PKC isozymes. In addition, Akt appears to associate to $\mathrm{PKC}-\delta$, through the $\mathrm{PH}$ domain and Akt was shown to phosphorylate $\mathrm{PKC}-\delta$ in vitro (Konishi et al. 1996). Thus a cross-regulation of PI3K/Akt and PKCs in the regulation of the MAPK cascade mediated by BK might be an interesting hypothesis, although it requires further investigation.
In conclusion, we have demonstrated that $\mathrm{BK}$ brings about a signalling pathway through the $B_{2}$ receptor involving a PI3K/Akt-dependent activation of ERK1/2 mediated by PKC $-\delta /-\varepsilon$ isozymes. These BK effects are of physiological importance since they lead to the stimulation of cell proliferation. Kinins also increase vascular permeability, thus facilitating tumour metastasis (Robert \& Gulick 1989, Marceau 1995) and, after infiltration into normal adjacent tissues, tumour cells can chemotactically attract inflammatory cells (Traub et al. 1997) thereby regulating angiogenesis (Dlamini et al. 1999). Accordingly, it would be reasonable to conclude that BK might have a significant role in breast cancer progression. Finally, the intracellular signalling and the mitogenic effects exerted by BK in the MCF-7 cell line are similar overall to those found in primary cultured breast epithelial cells, suggesting that MCF-7 may be a useful cell model in which to continue the studies on BK pathophysiology in the human breast.

\section{Acknowledgements}

The authors declare that there is no conflict of interest that would prejudice the impartiality of this scientific work.

\section{References}

Adomeit A, Graness A, Gross S, Seedorf K, Wetzker R \& Liebmann C 1999 Bradykinin $B_{2}$ receptor-mediated mitogen-activated protein kinase activation in COS-7 cells requires dual signalling via both protein kinase $\mathrm{C}$ pathway and epidermal growth factor receptor transactivation. Molecular Cell Biology 19 5289-5297.

Akimoto K, Takahashi R, Moriya S, Nishioka N, Takayanagi J, Kimura K, Fukui Y, Osada S, Mizuno K, Hirai S, Kazlauskas A \& Ohno S 1996 EGF or PDGF receptors activate atypical PKClambda through phosphatidylinositol 3-kinase. EMBO Journal 15 788-798.

Alessi DR, Cuenda A, Cohen P, Dudley DT \& Saltiel AR 1995 PD098059 is a specific inhibitor of the activation of mitogen-activated protein kinase kinase in vitro and in vivo. Journal of Biological Chemistry 270 27489-27494.

Alessi DR, Andjelkovic M, Caudwell B, Cron P, Morrice N, Cohen $\mathrm{P} \&$ Hemmings BA 1996 Mechanism of activation of protein kinase B by insulin and IGF-1. EMBO Journal 15 6541-6551.

Ankorina-Stark I, Haxelmans S \& Schlatter E 1997 Receptors for bradykinin and prostaglandin E2 coupled to $\mathrm{Ca} 2+$ signalling in rat cortical collecting duct. Cellular Calcium 22 269-275.

Barki-Harrington L \& Daaka Y 2001 Bradykinin induced mitogenesis of androgen independent prostate cancer cells. Journal of Urology 165 2121-2125.

Clark KJ \& Murray AW 1995 Evidence that the bradykinin-induced activation of phospholipase D and of the mitogen-activated protein kinase cascade involve different protein kinase $\mathrm{C}$ isoforms. Journal of Biological Chemistry 270 7097-7103.

Clements J \& Mukhtar A 1977 Tissue kallikrein and the bradykinin B2 receptor are expressed in endometrial and prostate cancers. Immunopharmacology 36 217-220.

Clerk A, Gillespie-Brown J, Fuller SJ \& Sudgen PH 1996 Stimulation of phosphatidylinositol hydrolysis, protein kinase $\mathrm{C}$ translocation, 
and mitogen-activated protein kinase activity by bradykinin in rat ventricular myocytes: dissociation from the hypertrophic response. Biochemical Journal 317 109-118.

Crowder RJ \& Freeman RS 1998 Phosphatidylinositol 3-kinase and Akt protein kinase are necessary and sufficient for the survival of nerve growth factor-dependent sympathetic neurons. Journal of Neuroscience 18 2933-2943.

Dikic I, Tokiwa G, Lev S, Courtneidge SA \& Schlessinger J 1996 A role for Pyk2 and Src in linking G-protein-coupled receptors with MAP kinase activation. Nature 383 547-549.

Dlamini Z, Raidoo D \& Bhoola K 1999 Visualisation of tissue kallikrein and kinin receptors in oesophageal carcinoma. Immunopharmacology 43 303-310.

Drube S \& Liebmann C 2000 In various tumour cell lines the peptide bradykinin $\mathrm{B}_{2}$ receptor antagonist, Hoe 140 (Icatibant), may act as mitogenic agonist. British Journal of Pharmacology 131 1553-1560.

el-Dahr SS, Figueroa CD, Gonzalez CB \& Muller-Esterl W 1997 Ontogeny of bradykinin $\mathrm{B}_{2}$ receptors in the rat kidney: implications for segmental nephron maturation. Kidney International 51 739-749.

Enomoto K, Furuya K, Yamagishi S, Oka T \& Maeno T 1995 Release of arachidonic acid via $\mathrm{Ca}^{2+}$ increase stimulated by pyrophosphonucelotides and bradykinin in mammary tumour cells. Cell Biochemistry and Function 13 279-286.

Flemming I, Fisslthaler B \& Busse R 1995 Calcium signalling in endothelial cells involves activation of tyrosine kinases and leads to activation of mitogen-activated protein kinases. Circulation Research 76 522-529.

Frey BM, Reber BF, Vishwanath BS, Escher GV \& Frey FJ 1999 Annexin I modulates cell functions by controlling intracellular calcium release. FASEB Journal 13 2235-2245.

Graness A, Adomeit A, Heinze R, Wetzker R \& Liebmann C 1998 A novel mitogenic signalling pathway of bradykinin in the human colon carcinoma cell line SW-480 involves sequential activation of a $G_{\mathrm{q} / 11}$ protein, phosphatidylinositol 3-kinase $\beta$, and protein kinase C $\varepsilon$. Journal of Biological Chemistry 273 32016-32022.

Graness A, Hanke S, Boehmer FD, Presek P \& Liebmann C 2000 Protein-tyrosine-phosphatase-mediated epidermal growth factor (EGF) receptor transinactivation and EGF receptor-independent stimulation of mitogen-activated protein kinase by bradykinin in A431 cells. Biochemical Journal 347 441-447.

Greco S, Muscella A, Elia MG, Salvatore P, Storelli C, Mazzotta A, Manca C \& Marsigliante S 2003 Angiotensin II activates extracellular signal regulated kinases via protein kinase $\mathrm{C}$ and epidermal growth factor receptor in breast cancer cells. Journal of Cellular Physiology 196 370-377.

Greco S, Muscella A, Elia MG, Romano S, Storelli C \& Marsigliante S 2004 Mitogenic signalling by B2 bradykinin receptor in epithelial breast cells. Journal of Cell Physiology 201 84-96.

Greco S, Elia MG, Muscella A, Romano S, Storelli C \& Marsigliante S 2005 Bradykinin stimulates cell proliferation through an ERK1/2-dependent mechanism in breast cancer cells in primary culture. Journal of Endocrinology 186 291-301.

Hall JM 1992 Bradykinin receptors: pharmacological properties and biological roles. Pharmacological Therapy 56 131-190.

Hawes BE, Luttrell LM, van Biesen T \& Lefkowitz RJ 1996 Phosphatidylinositol 3-kinase is an early intermediate in the G $\beta \gamma$-mediated mitogen-activated protein kinase signalling pathway. Journal of Biological Chemistry 271 12133-12136.

Hermann A, Buchinger P \& Rehbock J 1995 Visualization of tissue kallikrein in human breast carcinoma by two-dimensional Western blotting and immunohistochemistry. Biological Chemistry Hoppe-Seyler 376 365-370.

Jaffa AA, Miller BS, Rosenzweig SA, Naidu PS, Velarde V \& Mayfield RK 1997 Bradykinin induces tubulin phosphorylation and nuclear translocation of MAP kinase in mesangial cells. American Journal of Physiology 273 F916-F924.
Konishi H, Matsuzaki H, Tanaka M, Ono Y, Tokunaga C, Kuroda S \& Kikkawa U 1996 Activation of RAC-protein kinase by heat shock and hyperosmolarity stress through a pathway independent of phosphatidylinositol 3-kinase. PNAS 93 7639-7643.

Kranenburg O, Verlaan I, Hordijk PL \& Moolenaar WH 1997 Gi-mediated activation of the Ras/MAP kinase pathway involves a $100 \mathrm{kDa}$ tyrosine-phosphorylated Grb2 SH3 binding protein, but not Src nor Shc. EMBO Journal 16 3097-3105.

Lafon C, Mazars P, Guerrin M, Barboule N, Charcosset JY \& Valette A 1995 Early gene responses associated with transforming growth factor-beta 1 growth inhibition and autoinduction in MCF-7 breast adenocarcinoma cells. Biochimical et Biophysica Acta $\mathbf{1 2 6 6}$ 288-295.

Ma JX, Wang DZ, Ward DC, Chen L, Dessai T, Chao J \& Chao L 1994 Structure and chromosomal localisation of gene (BDKRB2) encoding the bradykinin B2 receptor. Genomics 23 362-369.

Marceau F 1995 Kinin B1 receptors: a review. Immunopharmacology 30 1-26.

Moriya S, Kazlauskas A, Akimoto K, Hirai S, Mizuno K, Takenawa T, Fukui Y, Watanabe Y, Ozaki S \& Ohno S 1996 Platelet-derived growth factor activates protein kinase $\mathrm{C}$ epsilon through redundant and independent signaling pathways involving phospholipase C gamma or phosphatidylinositol 3-kinase. PNAS 93 151-155.

Muscella A, Greco S, Elia MG, Storelli C \& Marsigliante S 2003 $\mathrm{PKC}-\zeta$ is required for angiotensin II-induced activation of ERK and synthesis of c-fos in MCF-7 cells. Journal of Cellular Physiology 197 61-68.

Naraba H, Ueno A, Kosugi Y, Yoshimura M, Murakami M, Kudo I \& Oh-ishi S 1998 Agonist stimulation of $\mathrm{B}_{1}$ and $\mathrm{B}_{2}$ kinin receptors causes activation of the MAP kinase signalling pathway, resulting in the translocation of AP-1 in HEK 293 cells. FEBS Letters 435 96-100.

Norby JG 1988 Coupled assay of $\mathrm{Na}^{+}, \mathrm{K}^{+}$-ATPase activity. Methods in Enzymology 156 116-123.

Pesquero JB \& Bader M 1998 Molecular biology of the kallikrein-kinin system: from structure to function. Brazilian Journal of Medical and Biological Research 31 1197-1203.

Plendl J, Snyman C, Naidoo S, Sawant S, Mahabeer R \& Bhoola KD 2000 Expression of tissue kallikrein and kinin receptors in angiogenic microvascular endothelial cells. Biological Chemistry $\mathbf{3 8}$ $1103-1115$

Regoli D \& Barabè J 1980 Pharmacology of bradykinin and related peptides. Pharmacological Review 32 1-46.

Riera MF, Meroni SB, Pellizzari EH \& Cigorraga SB 2003 Assessment of the roles of mitogen-activated protein kinase and phosphatidyl inositol 3-kinase/protein kinase B pathways in the basic fibroblast growth factor regulation of Sertoli cell function. Journal of Molecular Endocrinology 31 279-289.

Robert RM \& Gulick WJ 1989 Bradykinin receptor number and sensitivity to ligand stimulation of mitogenesis by expression of mutant ras oncogene. Journal of Cellular Science 94 527-535.

Roymans D \& Slegers H 2001 Phosphatidylinositol 3-kinases in tumor progression. European Journal of Biochemistry 268 487-498.

Traub O, Monia BP, Dean NM \& Berk BC 1997 PKC-epsilon is required for mechano-sensitive activation of ERK1/2 in endothelial cells. Journal of Biological Chemistry 272 31251-31257.

Vavrek R \& Stewart JM 1985 Competitive antagonists of bradykinin. Peptides 6 161-164.

Vlahos CJ, Matter WF, Hui KY \& Brown RF 1994 A specific inhibitor of phosphatidylinositol 3-kinase, 2-(4-morpholinyl)-8phenyl-4H-1-benzopyran-4-one (LY294002). Journal of Biological Chemistry 269 5241-5248.

Wennstrom S \& Downward J 1999 Role of phosphoinositide 3-kinase in activation of Ras and mitogen-activated protein kinase by epidermal growth factor. Molecular Cell Biology 19 4279-4288. 
Wiernas TK, Davis TL, Griffin BW \& Sharif NA 1998 Effects of bradykinin on signal transduction, cell proliferation, and cytokine, prostaglandin E2 and collagenase-1 release from human corneal epithelial cells. British Journal of Pharmacology 123 1127-1137.

Zhang J, Falck JR, Reddy KK, Abrams CS, Zhao W \& Rittenhouse SE 1995 Phosphatidylinositol $(3,4,5)$-trisphosphate stimulates phosphorylation of pleckstrin in human platelets. Journal of Biological Chemistry $27022807-22810$.

Zwick E, Daub H, Aoki N, Yamaguchi-Aoki Y, Tinhofer I, Maly K \& Ullrich A 1997 Critical role of calcium-dependent epidermal growth factor receptor transactivation in PC12 cell membrane depolarization and bradykinin signalling. Journal of Biological Chemistry 272 24767-24770.

Received in final form 22 September 2005

Accepted 26 September 2005

Made available online as an Accepted Preprint 2 November 2005 